\title{
The contamination of young people's notions about narcotics and psychoactive substances as a threat to psychological security
}

Yury P. Zinchenko ${ }^{\mathrm{a}}$, Olga Yu. Zotova ${ }^{\mathrm{b}^{*}}$, Lyudmila V. Tarasova ${ }^{b}$, Igor V. Gaidamashko ${ }^{c}$

a Psychology Faculty, Lomonosov Moscow State University, Moscow, Russia

bocial Psychology Faculty, Liberal Arts University-University for Humanities, Ekaterinburg, Russia

${ }^{c}$ Institute of Cybernetics, Moscow Technological University (MIREA), Moscow, Russia

^Corresponding author. E-mail: oiambusheva@mail.ru

The study described in this article investigated contemporary young people's perceptions of drugs and psychoactive substances (PAS). In the course of the research the following hypothesis was tested: in young people's perceptions about drugs and PAS there are differences in emotional coloring, coherence, and tolerance. J.-C. Abric's structural approach was used as the basic methodology. The free-associations method provided the bulk of the empirical material. The results obtained were processed via prototypic analysis (by P. Vergès's method), indexing of emotional associations (by E.E. Pronina's method), and frequency and content analysis.

As a result the core and the periphery of the perceptions of youth about drugs and PAS were described, and generalized notional categories that synthesize the structural elements of the perceptions were identified. The study revealed that the perceptions of young people about drugs and PAS do differ in coherence, tolerance, and emotional coloring. Perceptions of drugs are firm, consistent, and negative, while perceptions of PAS are less coherent but dynamic and have an ambivalent emotional coloration. The results are of prognostic importance for understanding young people's attitudes toward drugs and PAS and can be used to design programs and measures directed to the prevention of PAS and drug abuse.

Keywords: perceptions, structure of perceptions, core and periphery of perceptions, perceptions of drugs, perceptions of psychoactive substances

\section{Introduction}

PAS use is far from being a new phenomenon. Throughout history PAS have been used for various purposes: from medical use to use in rituals and ceremonies (Lang, 2004).For instance, alcohol use extends back at least 8,000years; tobacco has been used for about 7,000years; mention of opium use at least 7,000 years ago was found in Mesopotamia; cannabis under different names has been known in many cultures 
throughout history; reference to hallucinogenic mushrooms shows up in ancient Hindu texts, and there is archeological evidence of their use in 7500 B.C. Much evidence demonstrates that alcohol abuse and the civil unrest associated with it have been widespread throughout history. PAS intake used to be and still is a part of human behavior. Drug dependence "represents a complex of medico-biological, personal and socio-biological disorders and maladjustments where cause-and-effect relationships form complicated feedback loops and paths and PAS can become a means of personality disintegration" (Petrenko, 2009, p. 275).

According to the United Nations Office on Drugs and Crime (2014), every year about 200,000 people worldwide die from drug abuse; the use of forbidden narcotics will grow by $25 \%$ by 2050 ; and this increased use is being triggered by the growth of urbanization, industrialization, and population in developing countries.

A more precise understanding of the reasons for PAS use implies a certain structure for that use that likely includes a wide range of biological, psychological, social, and cultural factors. In 1977, George Angel, a psychiatrist, offered a biopsycho-social model of PAS use (Angel, 1977):

Biological factor

- Genetic vulnerability to risk factors

- Genetic vulnerability to pharmacological medication effects

- Pharmacological medication effects

Psychological factor

- Training, experience

- Self-esteem

- Cultural and spiritual beliefs

- Stress and style of coping with crises

- Mental and psychological health

Sociocultural factor

- Sociocultural environment

- Economic and ecological conditions

- Exposure to risk and the character of defensive factors (including influence, social networks, and social identity)

All these factors dynamically interact and change in the course of time.

Social and cultural differences also affect PAS use. In particular, some religions restrict or forbid the use of some pharmaceutical products (Mormons, for example, do not drink tea or coffee because of a caffeine taboo). Other confessions integrate substances into rituals and rites. Because of these religious directives, the problem of PAS use and proper preventive measures ought to be interpreted in the context of specific cultures and their features. Asmolov states: "By considering the stereotypical behavior accepted in a certain country one can predict to a greater or lesser extent typical social actions of an individual as a member of this or that social group"(2001, p. 74).

Addiction, or neuro-adaptation, occurs when a drug is necessary for an organism to function normally. Addiction has a physiological component - that is, cells adjust to the repeated effects of a pharmaceutical product and then require the given substance in order to gain homeostasis. 
Psychoactive agents also cause psychological dependence, in which a person must take a certain substance to cope with such emotional states as anxiety, anger, depression, guilt, and boredom (Ryder, Salmon, \& Walker, 2001).

Different approaches understand the term motive or another notion describing its functions to trigger one's behavior as the purpose of action realized by the subject, unconscious drives determining observable behavior patterns (psychoanalysis), general organismal activation associated with the actualization of needs external relative to the organism (drive theory), or the subject stimulus or cue that triggers this or that behavior program (behaviorism, ethology), etc. (Petrenko, 1988, p. 207)

Modern experts give two main reasons for narcomania: drug takers are motivated to use drugs to experience the effect of positive agents (hedonistic consequences of using drugs) and to avoid a symptom of withdrawal. "From a motivational point of view dependence can be equated with negative affect development" (Koob, 1997, p. 13).

PAS use can negatively influence the well-being of individuals, families, communities, and countries. PAS abuse is associated with mental health disorders including suicide. Foreign surveys demonstrate the dynamics of addiction development with their traumatic impacts (Table1).

Table 1. Drug-use levels

\begin{tabular}{|c|c|}
\hline Level & Definition \\
\hline Abstinence & No drug use. \\
\hline Experimental & Trying a drug and using only once or a few times. (e.g., using LSD once). \\
\hline Recreational & $\begin{array}{l}\text { Using a drug for leisure. The use is usually planned and controlled, and } \\
\text { may be specific to particular social situations or settings, such as parties, } \\
\text { clubs or at } \\
\text { home with friends. (e.g., taking ecstasy at a dance party). }\end{array}$ \\
\hline Regular & $\begin{array}{l}\text { Using a drug as a normal part of one's lifestyle, although use may still be } \\
\text { controlled. (e.g., a glass or two of wine with dinner). }\end{array}$ \\
\hline Dependence & $\begin{array}{l}\text { Using a drug a lot and needing it to feel "normal", to cope with day-day } \\
\text { problems, or to stop the symptoms of withdrawal (e.g., using heroin three } \\
\text { times a day and feeling physically sick if heroin is not used). }\end{array}$ \\
\hline Hazardous & $\begin{array}{l}\text { Using a drug in such a way that it will probably cause harm, but has not yet } \\
\text { done so. This includes taking serious risks when using a drug, such as: tak- } \\
\text { ing excessive amounts of the drug; using a combination of drugs that may } \\
\text { interact with each other; sharing injecting equipment; or driving under the } \\
\text { influence of the drug. }\end{array}$ \\
\hline Harmful & $\begin{array}{l}\text { Drug use that has demonstrably led to harm - physical, social or emo- } \\
\text { tional. }\end{array}$ \\
\hline
\end{tabular}

Source: Quoted in Rickwood D., Crowley M., Dyer K., Magor-Blatch L., Melrose J., Mentha H. \& Ryder D., 2005. p. 9; from Pols \& Hawks (1992).

Contemporary young people face a lot of risks including drug abuse, violence, and AIDS/HIV. The risk of becoming a drug addict involves relations between two 
aspects: risk factors (for instance, family history of addiction, relations with peer drug-takers, aggressive behavior, low self-control) and defensive factors (for example, parents' support) (Wills, McNamara, Vaccaro, \& Hirky, 1996). The level of interpersonal trust also matters. "Mistrust blocks access to the emotional, intellectual, and activity-related resources supporting life and undermines faith in the possibility of virtue and morality" (Dontsov \& Perelygina, 2014b, p. 40).Risk and defensive factors can be biological, psychological, or of a sociocultural character.

Early-childhood interactions take place within the family setting and can be positive or negative. Children are more often exposed to risk when there is:

- a lack of safety within the family circle

- an ineffective upbringing

- a chaotic family atmosphere

- a lack of bonding with adults

- drug abuse among parents

These factors interrupt family ties and threaten a child's feeling of security. However, a family can be a defensive factor when:

- a strong bond exists between the child and the family

- the parents are involved in the child's life

- the child's upbringing meets the material, emotional, cognitive, and social needs of the child

- the parents provide fixed limits and consistent discipline

Finally, critical or sensitive periods in a child's development can increase the effectiveness of defensive factors. Mutual affection and emotional bonds between parents and children, as a rule, are begun during infancy and early childhood. If such relationships do not develop during childhood, a family is unlikely to serve as a defensive factor in a child's further life. Dontsov argues that "not less than $3 / 4$ of all children and adults irrespective of gender actively discuss positive and negative events in their life with parents, intimate partners, friends" (2014, p. 440). A deficit of parental warmth and the presence of family conflicts are key predictors of teenagers' behavior problems and depression (Spoth, Kavanagh, \& Dishion, 2002). Healthy family relations provide a "protective capsule" for children even though they are later subject to risk factors(for instance, stress and poverty) (Galambos, Barker, \& Almeida, 2003).

Other risk factors are connected with a child's relationships outside the family: at school, with peers, with teachers. Communication problems within a child's family and school group can be detrimental to the child's emotional, cognitive, and social development. Among social risk factors are the following (Dishion \& Owen, 2002; Kellam, Brown \& Fleming, 1982; Smith \& Fogg, 1979):

- inappropriate in-class behavior (aggressiveness and impulsiveness)

- poor academic record

- companionship with peers taking drugs

Boys' aggressive behavior and girls' learning difficulties are seen as major causes of interpersonal problems among children of the same age. These problems, 
in turn, can lead to social isolation and deviant behavior including drug use. Research indicates that children aged 7-9 with poor academic records and inadequate social behavior are likely to take PAS at the age of 14-15 (Robertson, David, \& Rao, 2003).

When the time to leave lower school comes and emotional bonds with parents and teachers disappear, teenagers become increasingly affected by a wide circle of age-mates and spend more time without any supervision. Less parental control and involvement increase the risk of PAS use, aggression, and violence (Dishion, Patterson, Stoolmiller, \& Skinner, 1991).

Among psychological factors prompting conditions for teenagers' drug abuse the most important one is a dysfunctional family (Lichko, 1997).In addition, numerous surveys show that many teenage drug addicts have grown up in a singleparent family. Family problems serve as a background that pushes teenagers to become asocial, especially those with certain types of character (Kurek, 1996). Gannushkin (1933/1964) arguedthat constitutional proneness to drug addiction is most characteristic of people with epileptoid, unstable, cycloid, and hysteroid accentuations. The risk of drug abuse is higher for those with epileptoid and hysteroid accentuations. People with hyperthymic temperament express interest in hallucinogenic substances and inhaling powder, which can evoke colorful, bright images, and they are inspired "to try it all." Teenagers with hysteroid accentuation prefer feeling good; they gain some sort of pacification that is produced by tranquilizers. Young people with schizoid personalities tend to use opiates in order to feel emotionally pleased. However, teenagers with epileptoid, unstable, and hyperthymic accentuations are prone to narcomania and toxicomania (Gannushkin, 1964).

The human life journey is first and foremost characterized by diverse events, and some of them are interpreted as traumatic.

The traumatic character of a certain event depends on the meaning it conveys for an individual, i.e., on a stressor's personal meaning. Indeed, one and the same event can traumatize one person, while another seems not to be piqued by it, i.e., there exist individual differences in perceiving and reacting to the given, concrete stressor. That is why without personal processes (ones that determine meaning formation) we cannot adequately define both stress intensity and the very fact of the event's stressful impact" (Magomed-Eminov, 1998, p. 170).

Traumatic events- "life focal points" (S.L. Rubinstein)-largely determine individuals' lives, both their psychological and physical health and their psychological ill-being. "In the modern age, the depersonification of social organizations does not eliminate sources of and grounds for tense situations that affect the individual" (Dontsov \& Perelygina, 2013).

In 1991, Antonyan and Guldan conducted a comparative semantic analysis aimed at indicating the motives for drug use and drug withdrawal among teenagers with asocial behavior (main group) and schoolchildren (control group). Members of both groups expressed curiosity about and interest in drug use. For this reason the question of curiosity as a specific motive should be investigated further. All the subjects intended "to get rid of troubles" with the help of narcotics. In situations where drug intake was likely, the control group appeared to be immune to age- 
mates' influence; they were more tempted by consciousness alteration, the opportunity to feel good. Asocial teenagers seemed to be more affected by peers (namely, by the oldest one in the group) when choosing a behavior pattern that favored drug use (Antonyan \& Guldan, 1991). Petrovskaya points out: "Human life performance as a chain of choices implies being grounded in inner orientations as well as in external conditions and circumstances" (2002, p.325).

In a study Brunelle, Cousineau, and Brochu (2005) identified the following reasons for drug use:

Curiosity. Many of the teenagers studied indicated that they tried drugs out of curiosity, simply to feel their effect. For the majority their first experiment took place in other teenagers' company.

Pleasure. Regardless of what level or stage of drug use was achieved by the teenagers, their initial motives remained hollow. They used such terms as fun and great. For experienced drug users, pleasure is the primary motive.

Family identity. Many of the teenagers started to take narcotics because of the example set by their parents, brothers, or sisters. Some changed from being passive observers to being active participants.

Age-mate affiliation. Drug use was also one way to join a group.

Desire to spend illegally gained income. Some of the teenagers explained that drug use was the only way to quickly get rid of illegally gained money (from drug trafficking or stealing).

Among the reasons for the significant vulnerability of youth is the instability of their self-concept. Some specific features of self-concept can act as a factor in drug addiction. Self-concept is shaped through the influence of the social milieu and defines a young person's interaction with it. Hence, the more unstable social factors are, the less stable self-concept is likely to be. One other important aspect of the self-concept of youth is body image. Because their bodies change and development never stops, the same happens to their self-concept, together with ways of interacting with the environment. Proneness to crises and conflicts is also explained by the fact that a young person experiences not only the need to join a certain social group but also, at the same, the need to separate from a habitual environment and even confront it in order to attain and to unleash the individual self. Self -perception is a powerful phenomenon that requires continual self-expression and discharge, but, simultaneously, it is indefinite, filled with the experiences of other people: parents, older friends, and other reputable people. This contradiction between potential ability and the real substance of activity generates inner tension the release of which becomes urgent and vital. In young people's opinions, the most effective way to defuse tension is often to engage in some form of deviant behavior, including drug-taking (Raigorodsky, 1996).

The study of social perceptions can be useful for understanding the dynamics of person/world relationships, especially with regard to health (Foster, 2003; Howarth, Forster, \& Dorrer, 2004). Although it seems natural to examine constructs that respondents use to describe drug-taking, only a small number of research papers in this field can be found. There exist works on perceptions of tobacco use (Echabe, Guede, \& Castro, 1994; Stjerna, Lauritzen, \& Tillgren, 2004), on perceptions 
about drug or alcohol abuse among particular groups of the population (da Silva \& Padilha, 2011), on parents whose children are drug-takers (Nuño-Gutiérrez, Álvarez-Nemegyei,\&Rodriguez-Cerda, 2008), on students (Cabral, Da Cruz Farate, \& Duarte, 2007),on teachers (Martini \& Furegato, 2008), and on heavy drinkers (Alvarez, 2004; da Silva \& de Souza, 2005). An article by Demers, Kishchuk, Bourgault, \& Bisson (1996) is of special interest. They considered relationships between strong alcohol use and eight social perceptions. They argue that perceptions should be examined independently of social context and the respondents' life experience.

Although many authors underscore the importance of cognitive and emotional processes for understanding behavior (Beck \& Freeman, 1990; Brown \& Harris, 1989; Lazarus, 1999), youth perceptions about drugs and PAS are not sufficiently attended to. Young people's views are not taken into account, even though they are a useful and significant source for inquiring closely into this big problem facing our civilization.

\section{Objective and tasks}

The goal of our study was to identify and analyze youth perceptions about drugs and PAS. We set the following tasks:

- to indicate the semantic content of the notions drugs and psychoactive substances and attitudes toward these phenomena in the everyday consciousness of young people

- to juxtapose the scope of meanings of and the emotional responses to drugs and PAS

- to define how well perceptions about drugs and PAS are formed in the everyday consciousness of young people and to discover the degree of stability of these perceptions

- to find out attitudes toward drug-takers

\section{Hypothesis}

Youth perceptions about drugs and PAS differ in coherence, stability, and emotional coloring: drug perceptions are fixed, coherent, and negatively charged; PAS perceptions are less coherent, are dynamic, and have ambivalent coloration.

\section{Method}

The methodological foundation of the survey's first stage was J.-C. Abric's structural approach (Abric, 2001).The free association method was chosen for identifying perceptions. The data obtained were further processed and analyzed with the help of prototypic analysis (Vergès, 1992), indexing of emotional associations (Pronina, 2000), and frequency and content analyses.

In the first stage of data processing, the structural elements of drug and PAS perceptions were defined. The analysis was performed for associations mentioned by at least five subjects. At the second stage content analysis was carried out to identify generalized notional categories synthesizing those associations that were included in the structure of perceptions under consideration. 
The sample consisted of students aged 18-23 $(M=20.96$; $S D=3.79)$ who were residents of Ekaterinburg and the Sverdlovsk region. The survey was administered to 267 people, 131 males and 136 females. The sample population correlates with a general one in key demographic parameters: gender, age, education, type of residence.

\section{Results}

With the use of the free-association method, 1,282 associations with the notion psychoactive substances were received in the course of the survey; on average these responses came to 4.8 per respondent. The list of notions contains 290 words and word combinations. For these words and combinations, 595 associations entered the PAS perception core zone and its periphery ( $46.41 \%$ of the total number of associations expressed by the respondents).

In the course of the empirical study 1,096 associations were given in response to the word narcotics, which is an average of 4.1 per subject. The list of concepts contains 189 different words and word combinations. For these words and combinations, 642 associations entered the core and periphery zones of perceptions about drugs ( $58.57 \%$ of the total number of associations produced by the respondents).

\section{Results analysis}

\section{The structure of PAS perceptions}

The analysis of the PAS perception core proves that this phenomenon was connected with narcotics, and in the respondents' consciousness it was associated with pills, alcohol, and energy (Table 2).

Table 2. The structure of $d r u g$ and PAS perceptions

\begin{tabular}{lll}
\hline \multicolumn{1}{c}{ Structural elements } & \multicolumn{1}{c}{ Associations (frequency; average ranking) } \\
\hline \multicolumn{1}{c}{ Notions } & \multicolumn{1}{c}{ Drugs } & \multicolumn{1}{c}{ PAS } \\
\hline Core zone & Addiction $(158 ; 2.17)$ & Narcotics $(78 ; 2.05)$ \\
& Disease $(139 ; 2.16)$ & Energy $(65 ; 2.44)$ \\
& Harm $(127 ; 2.29)$ & Alcohol $(59 ; 2.52)$ \\
& & Pills $(47 ; 2.66)$ \\
Zone of potential & Syringe $(44 ; 2.69)$ & "Weed" $(25 ; 2.58)$ \\
perception alteration & Destruction $(41 ; 2.78)$ & Smoking $(32 ; 3.04)$ \\
in the periphery & Death $(26 ; 2.89)$ & Music $(34 ; 3.52)$ \\
& Problems $(20 ; 2.99)$ & Creativity $(31 ; 3.11)$ \\
& Money $(19 ; 3.01)$ & Cigarettes $(21 ; 2.74)$ \\
& & Stimulation $(23 ; 2.69)$ \\
& & Medication $(21 ; 2.86)$ \\
Periphery perception & Adrenaline $(25 ; 2.56)$ \\
system itself & Loneliness $(25 ; 3.16)$ & Brain $(18 ; 3.11)$ \\
& Crime $(23 ; 3.34)$ & Club $(26 ; 3.23)$ \\
& Heroin $(20 ; 3.69)$ & Energy shots $(22 ; 3.21)$ \\
& & Novelty $(20 ; 3.16)$ \\
& & Efficiency $(20 ; 3.2)$ \\
& & Chemistry $(20 ; 3.21)$ \\
& & Taboo $(8 ; 3.02)$ \\
\hline
\end{tabular}


The core zone of PAS perceptions contains descriptions of PAS themselves"narcotics," "alcohol," "pills"-as well as their aftereffects-"energy." In other words, the core includes perceptions existing in society. As a rule, the meaning of these perceptions is negative ("narcotics"), although some of the perceptions have dual meanings ("alcohol" and "pills"). The notion of "energy" in the core zone indicates that the "arousal" generated by PAS was treated by the young people mostly as a source of energy, vitality. The core-zone elements are specified by the peripheral-zone elements: on the one hand, they describe PAS themselves as perceived by the youth: "narcotics," "alcohol," "pills" (in the core zone), and "weed," "cigarettes," "medication," "energy shots," "chemistry" (in the peripheral zone); on the other hand, the intake of PAS is illustrated by the associations "music" and "club", which makes it possible to conclude that PAS were an integral attribute of club culture in the consciousness of the youth. Lastly, the perceptions in the peripheral zone point to the consequences of PAS use: "creativity", "stimulation", "adrenaline", "novelty", "efficiency". To put it differently, the aftereffects of PAS use do not have negative coloring, although such elements as "taboo" have a place in the periphery; this placement correlates with the inclusion of the perception "narcotics" in the core zone.

\section{The structure of drug perceptions}

According to Table 2 the core zone of drugs contains the perceptions "addiction," "disease", and "harm". The zone of potential perception alteration includes "syringe," "destruction", "death", "problems", "money”. Lastly, the periphery perception system unites the elements "loneliness", "crime", and "heroin". The core-zone elements are specified by the periphery elements: on the one hand, these elements

indicate the physical consequences of drug intake- "addiction", "disease" (in the core zone), "destruction", "death" (in the periphery); on the other, they point out the social effects of drug intake: "problems", "loneliness", "crime" (in the periphery system). Thus, differences exist in the perceptions of PAS and drugs: PAS perceptions do not convey a pronounced negative evaluation, whereas drug associations in the core zone bear strictly negative emotional coloring ("addiction", "disease", "harm"). In addition, drug perceptions include the means of use: "syringe", "money", "heroin". Here we also observe another distinctive difference in PAS and drug perceptions: whereas PAS are taken via smoking and the ingestion of pep pills, drugs are associated with intravenous injections ("syringe", "heroin"). Drug perceptions do not describe their intake, while PAS perceptions give a clear picture of this aspect. We can thus conclude that psychoactive substances and their intake were more a part of the youths' practical experience than were drugs and their intake.

Elements of the drug-perception core zone coincide with narcomania-perception elements indicated in Beresina's survey (Beresina, 2011), as well as in the data of Bovina, Dvoryanchikov, Konoplyova, Kobalyov, and Konkin (2012). We can thus conclude that there is evidence of the equality of object perception and, hence, stability, sustainability, and a high degree of consistency in the youths' perceptions of drugs. 


\section{Comparative analysis of PAS and drug perceptions}

Comparison of the content and structure of youth perceptions of PAS and drugs allows us to conclude that their perceptions of PAS were less consistent and homogeneous than their drug perceptions. Such data as the numerical dominance of notions expressed in response to psychoactive substances over those expressed in response to drugs (290 and 189, correspondingly) confirm this conclusion. In addition, the frequency of associations in the core of drug perceptions was a lot higher than in the core of PAS perceptions. Thus, for instance, the notion "narcotics" (the most numerous in the core of PAS perceptions) was stated by just $29 \%$ of the respondents, while the notion "addiction" (the most numerous in the core of drug perceptions) was stated by $59 \%$ of the respondents. Finally, the core of the drug perceptions contained $66 \%$ of the total associations in its structure. In the case of the PAS perceptions, this indicator accounted for just $41 \%$ of the total.

In order to make generalizations, content analyses of the associations included in the core and the periphery zones of PAS perceptions and of drug perceptions were performed. The following data were obtained for the PAS perceptions: substances ("pills," "narcotics," "alcohol") constituted $37.01 \%$ of the associations, intake situations ("music", "club") constituted $17.41 \%$, and aftereffects ("energy", "efficiency") constituted $22.4 \%$. These categories thus made up $76.82 \%$ of the total. The following data were obtained for the drug perceptions: means ("syringe", "heroin")-11.9\%, physical effects ("death", "disease") - 28.25\%, social consequences ("loneliness", "problems")-22.31\%. In a restructured variant all these categories made up $62.46 \%$.

Thus, the drug perceptions in the consciousness of the young people in the study were mainly concerned the negative effects of their use, both physical and social $(50.56 \%)$. At the same time the negative character of the effects of PAS intake was represented to a smaller degree (22.4\%). "The social responsibility of siteowners and providers of electronic information whose content is detrimental to children's health and development" should be emphasized (Dontsov \& Perelygina, 2014a).There has been an intense media campaign aimed at building awareness of negative drug-intake effects, but PAS intake effects are given considerably less attention, and thus young people possess limited knowledge about the harm caused by PAS.

However, in regard to the substances themselves (drug or PAS), a reverse tendency can be observed. Drugs were much less represented in the consciousness of the youth than psychoactive substances (11.9\% and $37.01 \%$ correspondingly). One probable explanation is the greater availability (real or potential) of PAS for young people.

Further analysis involved categorization of PAS. All associations mentioned were divided into groups of PAS regarded as legal or illegal under Russian Federal legislation and international agreements. The free circulation of illegal PAS is forbidden; they are regulated by the state, and their distribution is restricted and subject to state control. None of the subjects mentioned such PAS as tea and coffee, which are taken on a regular basis. The most common legal PAS in the youths' perceptions were cigarettes, alcohol, and energy shots. Still, the representation of legal substances in their consciousness was much smaller than the representation 
of illegal ones, and perceptions about their aftereffects of illegal substances in comparison with the aftereffects of narcotics were insignificant. To put it differently, the young people in their consciousness mainly related narcotics to PAS, but they remained unaware of the aftereffects of their use when classifying them as PAS.

\section{The emotional component of PAS and drug perceptions}

To evaluate immediate affective reactions to the trigger words "PAS" and "narcotics," emotional indexing of the associations was conducted (by E.E. Pronina) - that is, the level of psychic tension upon presentation of these triggers was estimated by defining neutrality and polarity indexes for each stimulus.

Identification of the neutrality index (IN) produced the following results: the IN for the stimulus "narcotics" was -0.89; the IN for the stimulus "PAS" was - 0.2 . The IN value for the trigger "narcotics" can be interpreted as an intensification of and a tendency toward emotion. The IN for the stimulus "PAS" indicates instability of emotional equilibrium. So, the stimulus "narcotics" gave rise to a more pronounced emotional reaction than did the stimulus "PAS."

To discover the direction of this emotional response, the index of polarity (IP) was determined. The IP for the stimulus "narcotics" was -0.78 ; for the stimulus "PAS" it was 0.3 , which means that the prevailing emotions of the young people toward narcotics were negative, while PAS evoked ambivalent, contradictory emotions. In sum, their reactions to PAS were characterized by ambivalence and an inner conflict of emotions. Their response to narcotics was inner resistance at the emotional level.

\section{Conclusion}

The young people's commonplace perceptions of PAS were characterized by dynamism; they were at the stage of formation. But the young people's perceptions about narcotics were tolerant, coherent, and stereotypical. In our view, these results can be explained by the fact that psychoactive substances has become a household word quite recently. In addition, the way it is discussed compared with the notion narcot$i c s$ is a lot more ambiguous.

Comparing the emotional fullness of the perceptions of PAS and narcotics allows us to conclude that narcotics as a phenomenon had extremely negative coloring in the respondents' consciousness, while PAS are partly associated with positive emotions and, on the whole, had an ambivalent emotional meaning for the young people. Thus, "disease", "death", "harm" as drug-intake aftereffects were opposed to PAS-use aftereffects- "efficiency", "energy", "creativity." Therefore, it seems quite rational to clearly differentiate one notion from the other when they are used in the media, to avoid making them synonymous (since naming drugs PAS erodes the accepted perception of them as a negative phenomenon).

The ill-management of providing information about narcomania with the aim of preventing youth narcotism leads to diverse, tattered, and inconsistent youth perceptions about narcotism. Dramatically negative, emotional attitudes to the "drug taker" stereotype often coincide with interest in drug use. We observed divergences 
in motives and motivations that, in their turn, result from a mismatch of youthsubculture rules, norms, taboos, and realities and reflect cognitive dissonance in the perceptions of young people about the narcomania problem.

The analysis of youth perceptions about drugs and PAS provides the empirical platform required for development of preventive measures aimed at shaping antidrug sentiments among young people and reduced drug use. Sharply negative attitudes to drug-takers often coincide with interest in their use. Social perceptions play the role of particular filters through which information concerning drugs and their harm to health is passed. Accordingly, effective antidrug programs call for regular monitoring of young peoples' perceptions of drugs and PAS.

\section{Acknowledgements}

The article is written under the Russian Scientific Fund grant (project № 16-1800032) "Trust and personality subjective wellbeing as foundation of modern society psychological security".

\section{References}

Abric, J-C. (2001). Representations of the social: Bridging theoretical traditions. Oxford, UK: Blackwell.

Alvarez, A. A. (2004). Representacion social del alcoholismo de personas alcohólicas [Social representation of the alcoholism of alcoholic persons]. Psicologia em Estudo, 9(2), 151-162. doi: $10.1590 /$ S1413-73722004000200002

Angel, G. L. (1977). The need for a new medical model. Science, 196, 129-136. doi: 10.1126/ science. 847460

Antonyan, Y. M., \& Guldan, V. V. (1991). Kriminalnaja patopsihologija [Criminal pathopsychology]. Moscow: Nauka.

Asmolov, A. G. (2001). Psihologija lichnosti: Principy obshhepsihologicheskogo analiza [Personality psychology: Principles of general psychological analysis]. Moscow: Smysl.

Beck, A. T., \& Freeman, A. (1990). Cognitive therapy of personality disorders. New York: Guilford Press.

Beresina, E. B. (2011). Soderzhanie i struktura obydennyh predstavlenij o boleznjah v molodezhnoj srede [The content and structure of youths'everyday perceptions about diseases] (Unpublished thesis). Moscow: Lomonosov Moscow State University.

Bovina, I. V., Dvoryanchikov, N. V., Konoplyova, I. N., Kobalyov, M. A., \& Konkin, V. Y. (2012). Narkotiki i narkomany: Osobennosti social'nyh predstavlenij v dvuh gruppah molodezhi [Narcotics and drug takers: Specifics of social perceptions in two youth groups]. Psychological Science and Education, 3. Retrieved from http://psyedu.ru/journal/2012/3/3026.phtml

Brown, G. W., \& Harris, T. O. (1989). Life events and illness. New York: Guilford Press.

Brunelle N., Cousineau, M.-M., \& Brochu, S. (2005). Juvenile drug use and delinquency: Youths' accounts of their trajectories. Substance Use \& Misuse, 40, 721-734. doi: 10.1081/ JA-200055404

Cabral, L. R., Da Cruz Farate, C. M., \&Duarte, J. C. (2007). Representações sociais sobre o álcool em estudos do ensino superior [Social representations on alcohol in higher education students]. Revista Científica da Unidade de Investigação em Ciências da Saúde: Domínio de Enfermagem [Scientific Journal of the Research Unit in Health sciences: Nursing domain], 4, $69-72$. 
da Silva, S.E.D., \& Padilha, M. I. (2011). Life history and alcoholism: Social representations of adolescents [in Portuguese]. Revista Mineira de Enfermagem [Nursing Journal of Minas Gerais], 15(1), 70.

da Silva, S. E. D., \&de Souza, M. J. (2005). Alcoholic, yes; drunk, no: Social representations of abstemious alcoholics on alcoholism. Escola Anna Nery Revista de Enfermagem [Journal of the Anna Nery School of Nursing], 9(2), 293-295.

Demers, A., Kishchuk, N., Bourgault, C., \& Bisson, J. (1996). When anthropology meets epidemiology: Using social representations to predict drinking patterns. Substance Use \& Misuse, 31(7), 847-871. doi: 10.3109/10826089609063960

Dishion, T. J., \& Owen, L. D. (2002). A longitudinal analysis of friendships and substance use: Bidirectional influence from adolescence to adulthood. Developmental Psychology, 28(4), 480-491. doi: 10.1037/0012-1649.38.4.480

Dishion, T. J., Patterson, G. R., Stoolmiller, M., \& Skinner, M. (1991). Family, school, and behavioral antecedents to early adolescent involvement with antisocial peers. Developmental Psychology, 27, 172-180. doi: 10.1037/0012-1649.27.1.172

Dontsov, A. I. (2014). Fenomen zavisti: Homo invidens? [The phenomenon of envy: Homo invidens?]. Moscow: Eksmo.

Dontsov, A. I., \& Perelygina, E. B. (2013). Tense situations and the significance of stability for psychological security. Psychology in Russia: State of the Art, 6(2), 20-31. doi: 10.11621/ pir.2013.0202

Dontsov, A. I., \& Perelygina, E. B. (2014a). Humanities' approaches to the interpretation of criteria for singling out content exposing children to negative informational and psychological effects. Procedia - Social and Behavioral Sciences, 146, 134-140. doi: 10.1016/j. sbspro.2014.08.100

Dontsov, A. I., \& Perelygina, E. B. (2014b). Interpersonal confidence as a factor in the prevention of disorganized interaction. Psychology in Russia: State of the Art,7(1), 40-49. doi: 10.11621/ pir.2014.0105

Echabe, A. E., Guede, E. F., \& Castro, J. L. G. (1994). Social representations and intergroup conflicts: Who's smoking here? European Journal of Social Psychology, 24, 339.

Foster, J. L. H. (2003). Representational projects and interacting forms of knowledge. Journal for the Theory of Social Behaviour, 33, 231-244. doi: 10.1111/1468-5914.00216

Galambos, N. L., Barker, E. T., \& Almeida, D. M. (2003). Parents do matter: Trajectories of change in externalizing and internalizing problems in early adolescence. Child Development, 74, 578-594. doi: 10.1111/1467-8624.7402017

Gannushkin, P.B. (1964). Klinika psihopatij. Ih statika, dinamika, sistematika [Clinical psychopathy. Statics, dynamics, systematics] (pp. 116-252). In Collected works. Moscow: Meditsina. (Original work published 1933)

Howarth, C., Foster, J., \& Dorrer, N. (2004). Exploring the potential of the theory of social representations in community-based health research. And vice versa? Journal of Health Psycho$\log y$, 9, 229-243. doi: 10.1177/1359105304040889

Kellam, S. G., Brown, C. H. \& Fleming, J. P. (1982). Social adaptation to first grade and teenage drug, alcohol, and cigarette use: Developmental epidemiological research in Woodlawn. Journal of School Health, 52, 301-306. doi: 10.1111/j.1746-1561.1982.tb04627.x

Koob, G. F. (1997). Neurochemical explanations for addiction, Hospital Practice, April (Special Report), 13.

Kurek, N. S. (1997). Jemocional'noe obshhenie materi i docheri kak faktor formirovanija addiktivnogo povedenija v podrostkovom vozraste [Emotional bonds of mother and daughter as a factor in the formation ofadolescentaddictive behavior]. Voprosy psikhologii [Issues in Psychology], 2, 48-60. 
Lang, E. (2004). Drugs in society: A social history. In M. Hamilton, T. King, \& A. Ritter (Eds.), Drug use in Australia: Preventing harm (2nd ed., pp. 1-16). Melbourne: Oxford University Press.

Lazarus, R. S. (1999). Stress and emotion: A new synthesis. New York: Springer.

Lichko, A. E. (1977). Narkotizm (upotreblenie narkotikov) i podrostkovaja narkomanija [Narcotism (drug use) and teenagers' narcomania]. In Psihopatija i akcentuacii haraktera $u$ podrostkov [Psychopathy and the accentuation of character in adolescents] (pp. 84-92). Leningrad: Rech.

Magomed-Eminov, M. S. (1998). Transformacija lichnosti [The transformation of personality]. Moscow: Psychoanalytical Association.

Martini, J. G., \& Furegato, A. R. F. (2008). Teachers' social representations on drug use in a secondary school. Revista Latino-Americana de Enfermagem [Latin American Journal of Nursing], 16(Special), 601-606. doi: 10.1590/S0104-11692008000700016

Nuño-Gutiérrez, B. L., Álvarez-Nemegyei, J., \& Rodriguez-Cerda, O. (2008). Social representations used by the parents of Mexican adolescent drug users under treatment to explain their children's drug use: Gender differences in parental narratives. Adolescence, 43, 351-371.

Petrenko, V. F. (1988). Psihosemantika soznanija [The psychosemantics of consciousness]. Moscow: Moscow University Press.

Petrenko V. F. (2009). Psihosemantika izmenennyh sostojanij soznanija (na materiale gipnoterapii alkogolizma) [The psychosemantics of altered states of consciousness (at the example of alcoholism hypnotherapy)]. In L. Makarova (Ed.), Mnogomernoe soznanie: Psihosemanticheskaja paradigma [Multidimensional consciousness: The psychosemantic paradigm] (pp. 272-301). Moscow: Novy Hronograf.

Petrovskaya, L. A. (2002). Gumanisticheskij kontekst psihologicheskoj pomoshhi [The humanistic context of psychological support]. In G.M. Andreeva \& A.I. Dontsov (Eds.), Social'naja psihologija $v$ sovremennom mire [Social psychology in the modern world] (pp. 323-334). Moscow: Aspekt.

Pols, R., \& Hawks, D. V. (1992). Is there a safe level of daily consumption of alcohol for men and women? (2nd ed.). Canberra, Australia: National Health and National Research Council.

Pronina, E. E. (2000). Psihologicheskaja jekspertiza reklamy. Teorija i metodika psihotehnicheskogo analiza reklamy [Psychological expertise inadvertising. Theory and methods of the psycho-technical analysis of advertising]. Moscow: RIP-Holding.

Raigorodsky, D. Y. (Ed.) (1996). Teorii lichnosti v zapadnoevropejskoj i amerikanskoj psihologii [Personality theory in Western and American psychology]. Samara, Russia: Bakhrakh.

Rickwood D., Crowley M., Dyer K., Magor-Blatch L., Melrose J., Mentha H. \& Ryder D. (2005). Perspectives in psychology: Substance use. Melbourne, Australia: The Australian Psychological Society Ltd.

Robertson, E. B., David, S. L., \& Rao, S. A. (2003). Preventing drug use among children and adolescents. NIH Publication 04-4212(A). Bethesda, MD: National Institute on Drug Abuse.

Ryder, D., Salmon, A., \& Walker, N. (2001). Drug use and drug related harm: A delicate balance. Melbourne: IP Communications.

Smith, G. M., \& Fogg, C. P. (1979). Psychological antecedents of teenage drug use. Research in Community and Mental Health, 1, 87-102.

Spoth, R. L., Kavanagh, K., \& Dishion, T. J. (2002). Family-centered preventive intervention science: Toward benefits to larger populations of children, youth, and families. Prevention Science, 3, 145-152. doi: 10.1023/A:1019924615322

Stjerna, M.-L., Lauritzen, S. O., \& Tillgren, P. (2004). "Social thinking" and cultural images: Teenagers' notions of tobacco use. Social Science \& Medicine, 59, 573-583. doi: 10.1016/j. socscimed.2003.11.003 
United Nations Office on Drugs and Crime (2014). World Drug Report2014. United Nations sales no. E.14.XI.7. Vienna: United Nations Office on Drugs and Crime.

Vergès, P. (1992). Lévocation de l'argent: Une méthode pour la définition du noyau central d'une representation [The evocation of money: A method for the definition of the central core of a representation]. Bulletin de Psychologie, 45(405), 203-209.

Wills, T. A., McNamara, G., Vaccaro, D., \& Hirky, A. E. (1996). Escalated substance use: A longitudinal grouping analysis from early to middle adolescence. Journal of Abnormal Psycho$\log y, 105,166-180$. doi: 10.1037/0021-843X.105.2.166

Original manuscript received January 24, 2016

Revised manuscript accepted March 09, 2016

First published online June 30, 2016 